Relations industrielles

Industrial Relations

\title{
Liste des appréciateurs 1979
}

List of Referees 1979

Volume 34, numéro 4, 1979

URI : https://id.erudit.org/iderudit/029032ar

DOI : https://doi.org/10.7202/029032ar

Aller au sommaire du numéro

Éditeur(s)

Département des relations industrielles de l'Université Laval

ISSN

0034-379X (imprimé)

1703-8138 (numérique)

Découvrir la revue

Citer ce document

(1979). Liste des appréciateurs 1979. Relations industrielles / Industrial Relations, 34(4), 842-842. https://doi.org/10.7202/029032ar

Tous droits réservés (C) Département des relations industrielles de l'Université Laval, 1979
Ce document est protégé par la loi sur le droit d'auteur. L'utilisation des services d'Érudit (y compris la reproduction) est assujettie à sa politique d'utilisation que vous pouvez consulter en ligne.

https://apropos.erudit.org/fr/usagers/politique-dutilisation/ 


\section{Liste des appréciateurs 1979 1979 List of Referees}

\author{
ARONSON, Robert \\ Cornell University \\ ARTHURS, Harry \\ York University \\ BELANGER, Gérard \\ Université Laval \\ BELANGER, Laurent \\ Université Laval \\ BERGERON, Jean-Louis \\ Université de Sherbrooke \\ BERNIER, Jean \\ Université Laval \\ BETCHERMAN, Gordon \\ Conseil économique du Canada \\ BLOUIN, Rodrique \\ Université Laval \\ BOIVIN, Jean \\ Université Laval \\ BOULARD, René \\ Université Laval \\ CÔTÉ, André C. \\ Université Laval \\ CONNAGHAN, C.J. \\ University of British Columbia \\ COUSINEAU, Jean-Michel \\ Université de Montréal \\ CRAIG, Alton \\ Université d'Ottawa \\ D'AOUST, Claude \\ Université de Montréal \\ DE BROUCKER, Patrice \\ Conseil économique du Canada \\ DION, Gérard \\ Université Laval \\ FRIC, Laurence \\ University of Western Ontario \\ GOLDENBERG, Shirley \\ McGill University \\ GUNDERSON, Morley \\ University of Toronto \\ JAIN, Hem C. \\ University of New Brunswick
}

HÉBERT, Gérard

Université de Montréal

HENDERSON, Dave

Conseil économique du Canada

INGERMAN, Sidney

Université McGill

LAFLAMME, Gilles

Université Laval

LAROUCHE, Viateur

Université de Montréal

LEMELIN, Maurice

Ecole des Hautes Etudes Commerciales

MELTZ, Noah

University of Toronto

MERCIER, Jacques

Université Laval

NEWTON, Keith

Conseil économique du Canada

PINDER, Craig

University of British Columbia

ROBACK, Léo

Université de Montréal

RONDEAU, Claude

Université Laval

ROY, Paul Martel

Université du Québec à Montréal

SANDERSON, George

Ministère du Travail (Ottawa)

SEXTON, Jean

Université Laval

SUBBARAO, A.V.

Université d'Ottawa

SWIMMER Gene

Carleton University

THERIAULT, Roland

Ecole des Hautes Etudes Commerciales

THWAITES, James

Université Laval

VERGE, Pierre

Université Laval

VINET, Alain

Université Laval

WEISS, Dimitri

Université de Paris I

WINDMULLER, J.P.

Cornell University 